\title{
Originalnost izuma Fausta Vrančića
}

\author{
Gojko Nikolić \\ Tekstilno-tehnološki fakultet Sveučilišta u Zagrebu \\ gojko.nikolic@ttf.hr
}

SAŽETAK: U radu je istražena originalnost triju izuma Fausta Vrančića sa stajališta današnjega poimanja izuma. Prvi izum koji je u radu istražen jest padobran, za koji je utvrđeno da Faust nije njegov izumitelj, već da ga je iznimno dobro tehnički unaprijedio, koncepcijski vrlo blisko suvremenim rješenjima. S obzirom na to da se uz padobran posvuda veže njegovo ime, mnoge će iznenaditi činjenica da Vrančić nije njegov izumitelj. Drugi izum koji je analiziran, a danas se nedovoljno ističe, odnosi se na mlin na plimu i oseku. Ideja nije nova, koristila se davno u povijesti, posebno u Irskoj i Engleskoj. Inovacija u Vrančićevu mlinu jest uporaba dvosmjernoga strujanja mora, pri čemu konstrukcija okretnoga pogonskoga vodeničnoga kola omogućuje njegovo okretanje uvijek u istom smjeru, neovisno o smjeru strujanja mora. Treća inovacija, koja se odnosi na Vrančićevo rješenje primjene statora i rotora kod vjetrenjače koje omogućuje korištenje vjetra iz bilo kojega smjera, danas se koristi kod turbina za razne fluide (vodu, paru, plinove).

Ključne riječi: padobran; mlin na plimu i oseku; Faust Vrančić; vjetrenjače

\section{Uvod}

Faust Vrančić proi hrvatski izumitelj (1993) Vladimira Muljevića bila je prva knjiga koja se bavila Vrančićevim izumima, ali ne na sustavan način, odnosno nisu istraživane njihove pojave u doba nastanka, kao ni mogući utjecaj radova prethodnika i suvremenika na njih. Teško je danas ustanoviti izvornoga autora inovacije jer je $u$ prošlosti kopiranje tuđih radova bilo uobičajeno, i to bez navođenja izvornoga autora. Naime, svi su željeli pridonijeti nekom novom uređaju odnosno ideji, prikazujući ih kao svoje jer se time stjecalo poštovanje, bolji položaj u društvu. $S$ obzirom na to da u renesansi nije bilo zakonske zaštite od kopiranja i plagiranja, autori su od vladara tražili zaštitu svojih izuma posebnim privilegijama. ${ }^{1}$

1 F. Vrančić dobio je privilegije od francuskoga kralja Luja XIII. i talijanskoga vojvode Cosima II. Medicija za svoju knjigu Machinae novae (G. Nikolić: Život i izumi Fausta Vrančića, treće prošireno i dorađeno izdanje, HATZ i POUZ, Zagreb 2018). 
Više od deset godina Gojko Nikolić, autor ovoga rada, sustavno je proučavao izume Fausta Vrančića, kao i radove njegovih prethodnika i suvremenika, objavivši rezultate tih istraživanja u knjizi Život $i$ izumi Fausta Vrančića, koja je doživjela tri izdanja (2015., 2016. i 2018). U odnosu na prvo, drugo i treće izdanje proširio je novim rezultatima istraživanjima te spoznajama i zaključcima, stoga je treće izdanje dvostruko opsežnije od prvoga. U radu Korištenje i plagiranje tudih ideja u renesansi $\mathrm{Ni}$ kolić ${ }^{2}$ upućuje na veći broj primjera kopiranja i plagiranja renesansnih inženjera, među kojima su bili i neki izumi Fausta Vrančića.

Za našu zemlju i tehničku struku posebno su zanimljiva istraživanja Vrančićevih izuma, kojima se ponosimo. Da bi se ispravno vrednovala Vrančićeva bogata ostavština, treba biti maksimalno korektan u definiranju originalnosti izuma, čemu će djelomično pridonijeti i ovaj rad, koji će uključivati prethodna istraživanja na koja će se nadovezati dio novih spoznaja, a time i novi zaključci. Pokušat će se striktno koristiti današnje pravilo što je izum i kada se on prihvaća, bez obzira je li izvorno rješenje lošije od njegova naknadnoga poboljšanja ili tehničkoga unaprjeđenja. Takav razvoj nekoga izuma u tehnici je logičan, ali te promjene ne dovode u pitanje izvornoga izumitelja. Nova inovacija može se priznati samo ako je toliko izmijenila izvorno rješenje da je stvoren novi proizvod, s novim značajkama ili svojstvima ${ }^{3}$, primjenjiv u praksi.

Kada se istražuju inovacije nastale prije više stotina godina, problem postaje teško dostupna literatura, unatoč sve učestalijoj digitalizaciji starih dokumenata.

\section{Ideja}

Ideja (grčki i $\delta \varepsilon \dot{\alpha}$ : misao, pojam), mnogoznačan pojam grčke filozofije, označuje i neki subjektivni misaoni sadržaj (pojam, zamisao, predodžbu) i objektivni aspekt neke pojave - oblik, bit, model. ${ }^{4}$ Šire gledano, ideja je nadahnuće, poticaj, prijedlog, zamisao, rješenje. U tehnici, a pogotovo danas, ideja koja je predvidivo ostvariva, temeljena na tehničkim mogućnostima, pokretač je izuma ili novih inovativnih rješenja. Ideja je iskra stvorena u mislima koja pokreće akciju. Ostalo je tehnika, bez obzira

2 G. Nikolić: Korištenje i plagiranje tuđih ideja u renesansi, Zbornik radova sa znanstveno-stručnog skupa Povijest i filozofija tehnike, Zagreb 2018., str. 263-302.

3 „Suštinski uvjeti koje neki izum mora zadovoljiti za priznanje patenta jesu novost u odnosu na postojeće stanje tehnike, inventivna razina (tj. neočiglednost onome koji je upoznat s dotičnim tehničkim područjem) $\mathrm{i}$ industrijska primjenjivost $\mathrm{tj}$. praktična primjenjivost $\mathrm{u}$ industrijskom opsegu «(»Što je patent?«, Državni zavod za intelektualno vlasništvo, 2015. /https:/www.dziv.hr/hr/intelektualno-vlasnistvo/patenti/sto-je-patent/; pristupljeno 13. X. 2018)

4 »ideja«, Hrvatska enciklopedija, Leksikografski zavod Miroslav Krleža (http://www.enciklopedija.hr/natuknica.aspx?id=26905; pristupljeno 13. X. 2018) 
koliko komplicirana i kompleksna bila i koliko mnogo različitih izvedbenih rješenja imala. Taj stav vrijedi oduvijek, iako izumiteljevu ideju neki, zbog pomanjkanja vlastitih ideja, umanjuju, a naglašavaju isključivo tehničko rješenje. Izvedeno tehničko rješenje zasigurno je važno, ali izumitelj je onaj koji je dao novu ideju, pokrenuo akciju i realizirao je na prihvatljiv način za uporabu. To je ujedno i pravilo o priznavanju izuma realizacijom originalne ideje (dovoljan je crtež ili skica) i prikaz zamišljene realizacije na jedan od mogućih načina, s mogućnošću uporabe proizvoda. Pri stvaranju nove ideje ili zamisli nekoga objekta ili postupka, izumitelj ih treba vizualizirati kako bi našao praktično rješenje, u pravilu načelno, bez detalja. Tada je ta ideja ostvariva i moguće ju je tehnički realizirati na određeni način. Danas je to razvojem tehnike posebno olakšano i omogućeno.

Danas se svako se novo poboljšano rješenje istoga izuma smatra tehničkim unapređenjem, dok se u doba renesanse smatralo velikom novošću i napretkom. Napredak gospodarstva i cijeloga društva, posebno u današnje vrijeme, nije moguć bez novih inovativnih rješenja koja »vuku naprijed«. Pogrešno je i uvriježeno mišljenje da su izumitelji isključivo ljudi s tim prirodnim darom. Iako je i to prisutno, obrazovanjem koje potiče znatiželju i inovativnost te postavljanjem sustava vrijednosti u društvu koje javno cijeni i potpomaže inovativnost, inovacija bi bilo daleko više i Hrvatska ne bi bila na začelju Europe. Kroz povijest, iako mala zemlja, imali smo mnogo izumitelja koji su svjetski priznati i koje često drugi slave kao svoje, a u nas su neki široj javnosti nepoznati. Trebali bismo više brinuti i upoznavati javnost s izumiteljima iz nedavne prošlosti i njihovim djelima kao stvaralačkom baštinom. Među njima su Nikola Tesla, Slavoljub Penkala, David Schwarz, Mario Puratić, Ivan Lupus-Vukić, Anton Lučić, Marcel Kiepach, Ivan Vučetić, Josip Belušić, Franjo Hanaman i još mnogo drugih.

\section{Izumi Fausta Vrančića}

Vrančićeve mnogobrojne izume može se ocjenjivati po tome koji se od njih u nekom novom tehničkom rješenju i danas primjenjuju. Autor ovoga rada ustanovio je osam takvih izuma, odnosno važnih tehničkih unapređenja ${ }^{5}$. Neki od njih zaslužuju da se s novim pristupom $i$ analizom ocijeni njihova izvornost $i$ inovativnost. $S$ obzirom na ograničenje opsega ovoga rada pozornost ćemo usmjeriti na tri izuma: padobran, mlin na plimu i oseku te rješenje korištenja usmjerivača struje vjetra - statora na rotor vjetrenjače.

5 G. Nikolić: Život i izumi Fausta Vrančića, treće prošireno i dorađeno izdanje, HATZ i POUZ, Zagreb 2018 


\section{Padobran}

Iako se ime Fausta Vrančića u javnosti često povezuje s padobranom (Homo volans), kao što je zaštitni znak Leonarda da Vincija njegov crtež Vitruvijeva čovjeka (Vitruvian Man, L'Uomo Vitruviano) ${ }^{6}$, ideja o padobranu kao sredstvu za skakanje s uzvišenih mjesta bez povrede prisutna je u raznim rješenjima više od 2000 godina. Legenda u knjizi Si fi kineskoga povjesničara Si M Chiana 90. pr. Kr. govori o bijegu sina cara Shuna koji se spasio skočivši s krova uz pomoć dvaju velikih bambusa. Kineski pak zapis iz 1180. godine opisuje bijeg lopova koji je skočio s minareta u Guang Dongu u Kini, držeći u rukama dva kruta suncobrana. ${ }^{7}$ Spominju se i artisti koji su skakali s uzvišenih mjesta, koristeći krute suncobrane (slika 1).

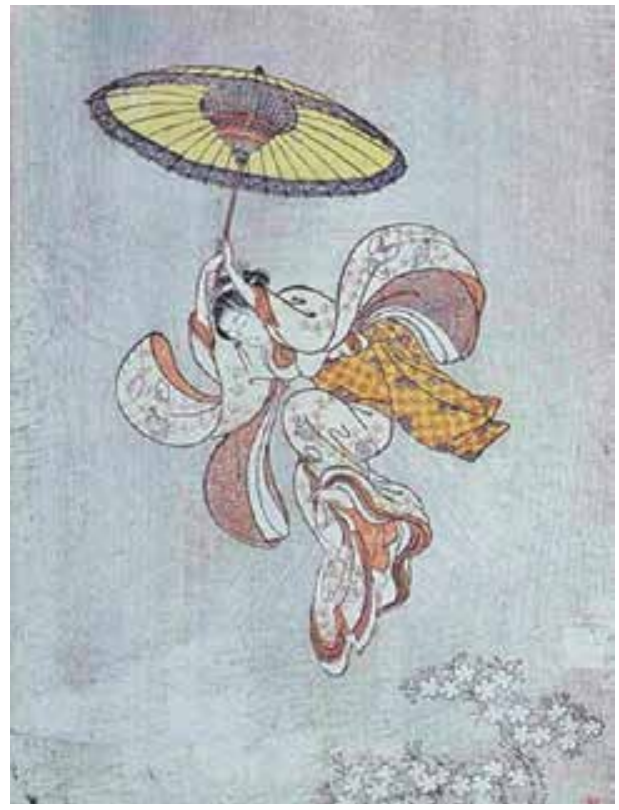

Slika 1. Djevojka skače s budističkoga hrama Kiyomizu-dere s krutim suncobranom, slika iz japanskoga kalendara Egoyomi, oko 1750.

(preuzeto s https://militaersport.hpage.de/ 18. V. 2017)

6 Leonardo nije prvi smjestio čovjeka u krug i kvadrat kao božanski i zemaljski simbol. Puno prije njega su to napravilo više izumitelja i inženjera. On je najdetalinije i slikarski najbolje izradio taj crtež i našao tih 18 dimenzijskih značajki tijela koje su međusobno ovisne (vidi detaljnije u G. Nikolić, Korištenje i plagiranje tudih ideja u renesansi, Zbornik radova sa znanstveno-stručnog skupa Povijest i filozofija tehnike, Zagreb 2018., str. 263-302).

7 E. i Chun-Chih Hadley-Ives: »Parachute Designed and Invented« (http://www.historylines. net/history/15th_cent/parachutes.html; pristupljeno 1. XI. 2015) 
U povijesti je zabilježeno ime španjolskoga Maura Armena Fermana koji je 855. skočio s tornja džamije u Córdobi. Napravio je labav plašt od svile, povezujući rubove s prečkama za koje se držao i skočio. Zrak koji je ušao u plašt ublažio je pad pa se prizemljio bez većih ozljeda ${ }^{8}$. Iako ga Arapi smatraju izumiteljem padobrana, Ferman to nije jer plašt nije uređaj oblikovan za prizemljenje bez ozbilinih posljedica.

Prvi dokumentirani uređaj ili naprava za siguran skok s uzvisina, rješenje je Francesca di Giorgia Martinija (1439-1501/02), ${ }^{9}$ renesansnoga slikara, arhitekta, vojnoga inženjera i izumitelja. Rukopis s crtežom njegova padobrana pronađen je u British Museumu, a objavio ga je White Lynn 1968. u djelu The Invention of the Parachute, a 1978. i u zbirci eseja Medieval Religion and Technology $y^{10}$ (slika 2). Rukopis potječe iz Italije i datiran je 1470. godine. Martinijev je padobran dobro zamišljen, stožasta oblika ali je neproporcionalno nacrtan. Padobranac se drži za poprečne letve, koje su učvršćene na kruti kružni okvir padobrana. Pretpostavljajući mogućnost da padobranca zabole ruke, držeći se cijelo vrijeme za prečke, predvidio je i osiguranje: padobranca je oko pojasa vezao s četirima nosivim užetima, simetrično vezanima na poprečne letve. Kako po svim kriterijima, od ideje do primjenjivoga rješenja, Martinijev padobran zadovoljava sve uvjete za priznavanje inovacije, sa sigurnošću možemo tvrditi da je Francesco di Giorgio Martini izumitelj padobrana. To što Martini nije definirao dimenzije padobrana niti ga isprobao nije važno za priznavanje inovacije.

Drugi dokumentirani padobran jest onaj Leonarda da Vincija iz 1485. On ga nije samo nacrtao, već je i odredio njegove dimenzije. Kupola njegova padobrana je piramidalnoga oblika. U natpisu pokraj skice naznačio je dimenzije u tekstu: »Se un uomo ha un padiglione di pannolino intasato che sia di 12 braccia per faccia e alto 12 , potrà gettarsi d’ogni grande altezza senza danno di sé«. Odredio je da baza padobrana (okvira) i visina iznose 12 firetinskih lakata (braccio fiorentino). Kako jedan lakat iznosi $0,583 \mathrm{~m}$, preračunate dimenzije su: baza iznosi oko $7 \times 7 \mathrm{~m}$, a visina piramidal-

8 »Abbas ibn Firnas«, Wikipedia (https://en.wikipedia.org/wiki/Abbas_ibn_Firnas; pristupljeno 20. III. 2017)

9 Francesco di Giorgio Martini (1439-1501/02) talijanski je renesansni slikar, kipar, arhitekt, izumitelj i dizajner. Napisao je između 1475. i 1495. Trattato di Architettura civile e militare, važno djelo koje se često povezuje s kasnijim radovima Leonarda da Vincija, koji je posjedovao jedan primjerak toga djela i na marginama pisao zabilješke. Osim arhitektonskih rješenja, projektirao je razne naprave i strojeve. Bavio se projektiranjem različitih vrsta vozila (auto-mobile), kod kojih su vitlima bili pokretani kotači vozila. Vidi E. M. Merrill: »The Trattato as Textbook: Francesco di Giorgio's Vision for the Renaissance Architect «, Architectural Histories, 2013. (http://journal.eahn.org/articles/10.5334/ah.at/; pristupljeno 18. V. 2017) i Mariano di facopo »Taccola« (1382-1453)(https:/www.youtube.com/watch?v=if3hUbIDQys; pristupljeno 15. V. 2016).

10 Poglavlje 11. (https://books.google.hr/books?id=quCh9tAWljcC\&printsec=frontcover\&hl=hr $\# \mathrm{v}=$ onepage\&q\&f=false; pristupljeno 6. XI. 2015) 
noga padobrana oko $7 \mathrm{~m}$. Dopisao je: »ognuno si potrà gettare da qualsiasi altezza senza alcun rischio«, tj. da svatko može s njim skočiti s bilo koje visine bez ikakva rizika $^{11}$. Daje upute da za izradu padobrana treba koristiti gusto tkano platno nepropusno za zrak. Izgleda da nije polagao dovoljno računa na to kako će se padobranac držati za padobran niti o njegovoj sigurnosti. Po gruboj skici, koju nažalost nije detaljnije razradio, može se zaključiti da se padobranac drži za užad. Nisu jasne dvije paralelne crte preko prsiju, koje bi mogle uputiti na to da je Leonardo ipak predvidio vezivanje padobranca užadima (slika 2). Bez obzira na uočene manjkavosti u pogledu veze između padobrana i padobranca, da Vinci je vrlo precizno naznačio mjere, koje pokazuju da je najvjerojatnije obavio neke pokuse, povezujući težinu padobranca i površinu padobrana. Za takvu pretpostavku nažalost nema potvrde u dokumentima, ali eksperimentiranje je bilo Leonardovo najvažnije načelo rada.
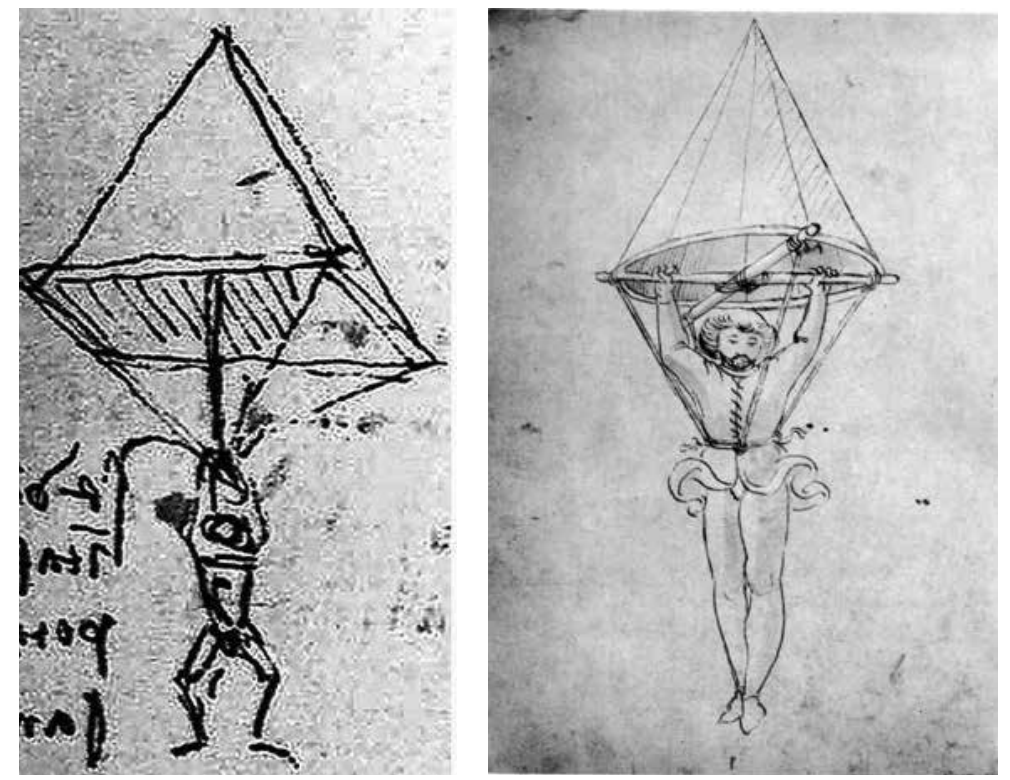

Slika 2. Prve konstrukcije padobrana: Francesca di Giorgija Martinija iz 1470. (lijevo) i Leonarda da Vincija iz 1485. (desno) ${ }^{12}$

11 »padobran« (https:/hr.wikipedia.org/wiki/Padobran; pristupljeno 10. IX. 2016)

12 Leonardo da Vinci, Images and Videos (https://www.britannica.com/biography/Leonardo-daVinci/images-videos; pristupljeno 5. XI. 2015) 
Potvrda da je da Vincijev padobran upotrebljiv bio je skok britanskoga padobranca Adriana Nicholasa 2000. Padobran je bio izrađen prema dimenzijama koje je naveo da Vinci, a koristili su se materijali dostupni u to doba ${ }^{13}$. Skok je ostvaren u Južnoj Africi podizanjem padobrana balonom na 3000 m, nakon čega je otkvačen zajedno s padobrancem Nicholasom (slika 3). Nicholas se nije usudio prizemljiti s tim padobranom, bojeći se da bi ga mogao ozlijediti drveni okvir težine približno $36 \mathrm{~kg}$, pa se odvojio od da Vincijeva padobrana na visini od približno $600 \mathrm{~m}$ i spustio rezervnim.

Drugi skok s padobranom istih dimenzija, ali bez kruta okvira i sa suvremenom padobranskom tkaninom, učinio je Olivier Vietti-Teppa 2008. u Payernu u blizini Ženeve. Skočio je s približno $600 \mathrm{~m}$ visine i prizemljio se s padobranom (slika 4), kojim je čak mogao donekle i upravljati ${ }^{14}$. Uspjela provjera funkcioniranja da Vincijeva padobrana upućuje na to da je on mjere padobrana najvjerojatnije dobio eksperimentalno jer su točne.

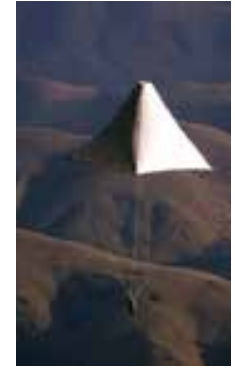

Slika 3. Skok Adriana Nicholasa 2000.15

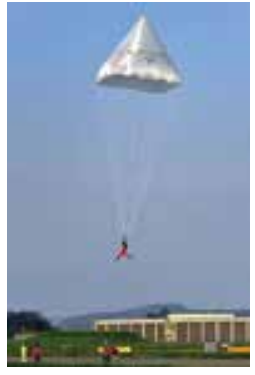

Slika 4. Skok Oliviera Vietti-Teppa $2008 .^{16}$

Padobran Fausta Vrančića najsličniji je suvremenom padobranu. Kako je Vrančić bio praktičar, što se vidi iz svih njegovih crteža i drugih uređaja koje je pedantno osmišljavao i do zadnjega vijka, shvatio je da je za padobran važna veličina površine (poput jedara), a ne oblik, te da je bitan sustav veza, čemu je posvetio punu pozornost. Zaključio je da čovjek cjelokupnom težinom ne može visjeti omotan oko struka, već da se užad treba postaviti preko prepona kao da se sjedi na njima. Gornji je dio omotao oko prsiju. Isto tako, radi zadržavanja vertikalnoga položaja padobranca, postavio je užad od prsiju preko ramena. Takav je sustav veza gotovo identičan suvre-

13 »padobran« (https://hr.wikipedia.org/wiki/Padobran; pristupljeno 10. IX. 2016)

14 I. Sparks: »Parachute that Da Vinci drew is made to work... after 523 years«, MailOnline, 28. IV. 2008. (http://www.dailymail.co.uk/news/article-562445/Parachute-Da-Vinci-drew-work--523-years. html; pristupljeno 1. XI. 2015)

15 D. Carrington: »The Da Vinci Parachute«, BBC News Online (http://www.angelfire.com/ electronic/awakening101/davinci-chute.html; pristupljeno 18. X. 2018)

16 »Swiss jumps using da Vinci-designed parachut«, Chinadaily, 28. IV. 2008. (http://www. chinadaily.com.cn/world/2008-04/28/content_6649092.htm; pristupljeno 18. X. 2018) 
menom (slika 5). Iako Vrančić nije uočio nepotrebnost kruta okvira, budući da otpor zraka drži površinu padobrana raširenom, ukrućenje velike površine platna izveo je nizom šavnih ojačanja po cijeloj dužini, što je značajka i suvremenih padobrana. ${ }^{17}$
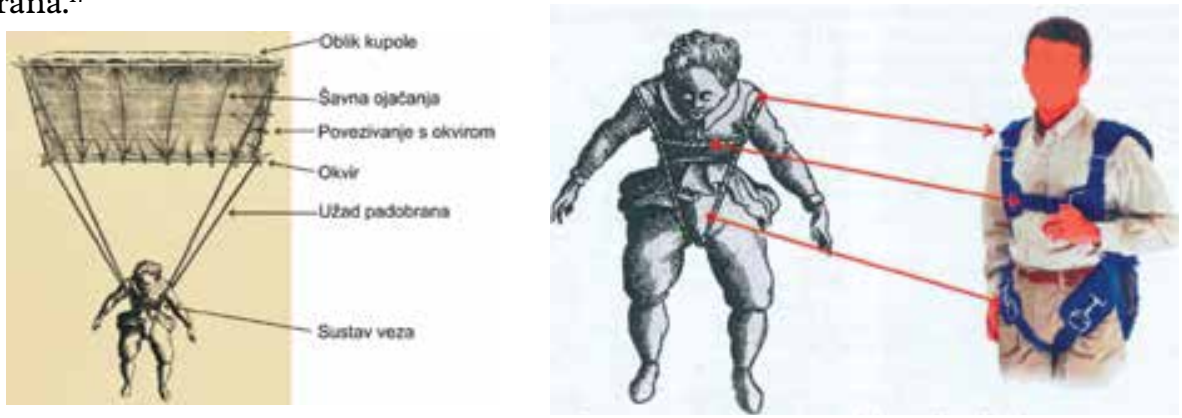

Slika 5. Prikaz osnovnih elemenata Vrančićeva padobrana (lijevo); usporedba veza Vrančićeva i suvremenoga padobrana (desno) ${ }^{18}$

Iako Vrančić nije dao dimenzije okvira padobrana, sam je padobran (»Homo volans«), kao i naputak da površina padobrana mora biti usklađena s težinom padobranca, opisao riječima:

U četverouglastom platnu za jedra, napetom pomoću četiri jednake motke i na četiri ugla dobro privezanom užetima, može se čovjek bez ikakve opasnosti sigurno spustiti s tornja ili s drugog visokog mjesta. Pa ako tada i ne bi bilo vjetra, ipak će snaga padajućeg covjeka proizvesti vjetar koji će zadržavati platno, kako ne bi prispio dolje s treskom, nego se polagano spustio. Ipak čovjekova mjera mora biti točno usklađena s veličinom platna. ${ }^{19}$

Vrančićev su padobran 2009. uspješno ispitali britanski padobranac Ray Armstrong i njegov prijatelj Alex Flint, izradivši padobran prema Vrančićevu crtežu, pri čemu su koristili svilenu Habotai tkaninu i bambusove motke, u Vrančićevo doba poznate i dostupne materijale. Proračunali su površinu padobrana te dobili dužine stranica od $5 \mathrm{~m}$. Padobran su pričvrstili za balon i podignuli na visinu od $1800 \mathrm{~m}$, odakle se padobranac Armstrong otkvačio i spustio. Nije se s njim prizemljio, kao ni Nicholas, strahujući od ozljeda zbog teška okvira padobrana. Zaključio je da je Vrančićev padobran ostvario sve zahtjeve koji se postavljaju i za suvremeni padobran. ${ }^{20}$

17 F. Vrančić: Machinae novae Fausti Verantii Siceni cum declaratione Latina, Italica, Hispanica, Gallica et Germanica. (pretisak), Novi Liber-Gradska knjižnica »Juraj Šižgorić«, Zagreb-Šibenik 1993; G. Nikolić: Život i izumi Fausta Vrančića, treće prošireno i dorađeno izdanje, HATZ i POUZ, Zagreb 2018.

18 Isto.

19 Isto.

20 E. Mahmutović: »Skok s replikom Vrančićeva padobrana s $1800 \mathrm{~m}$ «, Tehnička kultura, 28(2009) 229-230, str. 31-33. 


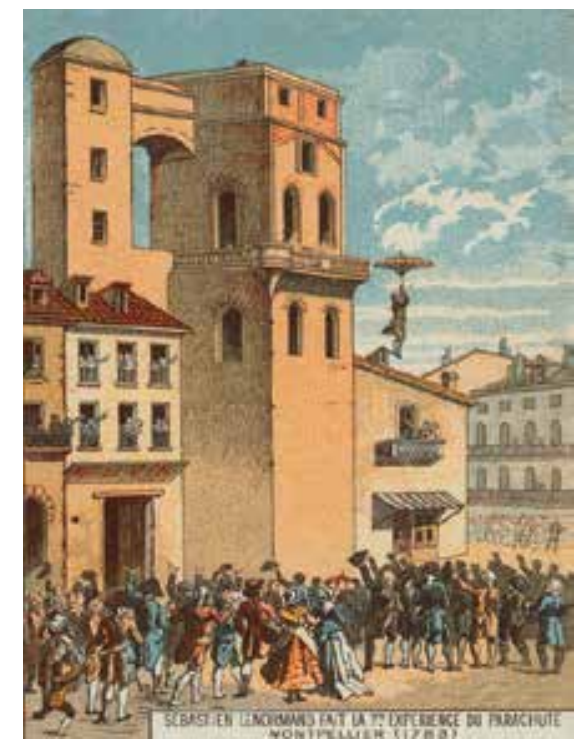

Slika 6. Skok Louis-Sébastiena Lenormanda s opservatorija u Montpellieru 1783. godine

Vrlo se često u povijesnim knjigama, člancima, katalozima muzeja, turističkim brošurama i na predavanjima netočno tvrdi da je Faust Vrančić skočio sa svojim padobranom i da je to detaljno opisao John Wilkins u svojoj knjizi Mathematical Magick or the Wonders that may be Performed by Mechanical Geometry, što nije točno. ${ }^{21} \mathrm{Na}$ kraju se može zaključiti da je Vrančić donio niz ispravnih i praktičnih zaključaka u vezi padobrana i da je njegov padobran daleko bolji od dva prethodno opisana. S obzirom na to je konstrukcija njegova padobrana vrlo slična suvremenoj, smatra ga se ocem suvremenoga padobrana. Ipak, to je samo tehničko poboljšanje već ranije razrađene ideje i konstrukcije pa se padobran Vrančiću ne može priznati kao njegov izum.

Francuzi smatraju da je izumitelj padobrana njihov fizičar Louis-Sébastien Lenormand (1757-1839), koji je 26. studenoga 1783. skočio s tornja opservatorija u Montpellieru (danas Tour de la Babote) koristeći »kruti suncobran« (slika 6). Kasnije je Lenormand osmislio svoj padobran, sa stožastom kupolom promjera 4,3 m, s velikim brojem gusto smještenih užadi koja nose sjedalo za padobranca, koji se za nj drži. To je prvi padobran bez krutih okvira, zasigurno preteča novih padobrana ${ }^{22}$. Prvi

${ }^{21}$ G. Nikolić: Letači fohna Wilkinsa među kojima nema Fausta Vrančića, Znanstveno stručno savjetovanje »4. Kulturno nasljeđe Ujević«, Krivodol, Imotski 2017., str. 151-160; Isti: Život i izumi Fausta Vrančića, treće prošireno i dorađeno izdanje, HATZ i POUZ, Zagreb 2018.

22 »Louis-Sébastien Lenormand«, Wikipedia

(https://en.wikipedia.org/wiki/Louis-S\%C3\%A9bastien_Lenormand; pristupljeno 15. X. 2018) 


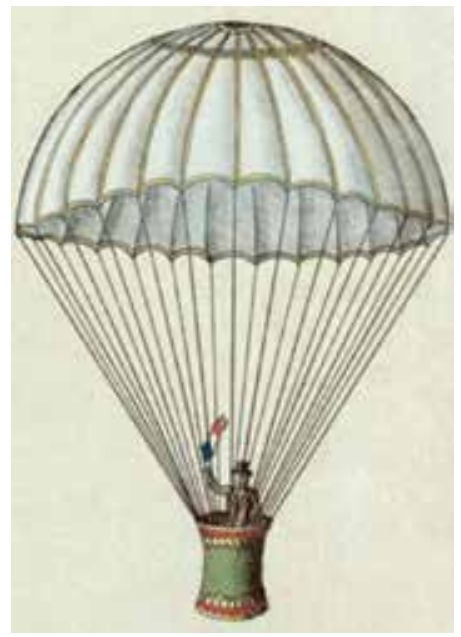

Slika 7. Garnerinov padobran iz 1797. godine

padobran s kupolom izradio je 1797. Francuz André-Jacques Garnerin (1769-1823). Promjer kupole iznosio je približno $10 \mathrm{~m}$, jednako kao i dužina užadi do košare. S njim je obavio probni skok iste godine (slika 7$){ }^{23}$

\section{Originalno rješenje mlina koji koristi plimu i oseku}

Za pokretanje vodeničnih kamena i mljevenje žitarica pri izgradnji mlinova koristila se još u srednjem vijeku plima i oseka. Prvi mlinovi na plimu i oseku izgrađeni u Irskoj u XI. st. Razlike između plime i oseke ovise o mjesečevu kalendaru, događaju se u različitom dobu dana i noći, a na pojedinim mjestima u Francuskoj i jugozapadnom dijelu Engleske sežu i do $12 \mathrm{~m}$.

Osvojivši 1066. godine Englesku, Willim Osvajač naručio je 1085. godine, u svrhu ubiranja poreza, izradu popisa vlasništva nad zemljom i nekretninama. Sljedeće je godine taj skup popisa, zajedno s kartama, uvezan u knjigu nazvanu Domesday Book, koja je sadržavala podatke o 13418 naselja u engleskim županijama južno od rijeka Ribble i Tees. Prema navodima iz te knjige, u Engleskoj je tada bilo 5624 vodenica. ${ }^{24}$ Jedan od navedenih mlinova na karti u Domesday Book bio je Elingov mlin na plimu i oseku, izgrađen na južnoj obali Velike Britanije. Iako vrijeme gradnje nije poznato, nagađa se da bi mogao datirati još iz rimskoga doba. Zna se da je bio u posjedu engleskoga kralja Johna, koji ga je prodao 1200 . godine, a potom je promijenio

23 »Louis-Sebastien Lenormand «, Alchetron (https://alchetron.com/Louis-S\%C3\%A9bastienLenormand; pristupljeno 18. X. 2018); »The first parachutist «, Bowie News, 22. X. 2016. (http://bowienewsonline.com/2016/10/the-first-parachutist/; pristupljeno 18. X. 2018)

24 The Domesday Book online (http://www.domesdaybook.co.uk/; pristupljeno 16. X. 2018); »vodenice«, Wikipedija (http://hr.wikipedia.org/wiki/Vodenice; pristupljeno 16. X. 2018). 
više vlasnika. Važan je zbog opisa načina rada takva mlina (slika 8). ${ }^{25}$ Kada plima raste, puni se akumulacijsko jezero i dok voda nije dosegnula osovinu vodeničnoga kola postoji razlika u razini akumulacijskoga jezera i mora pa mlaz vode struji iz jezera i okreće kolo (slika 8a). Kada se plimom razina mora podigne i dosegne osovinu pogonskoga kola, kolo se zaustavlja (slika 8b). Iako to nije opisano, brana kojom se regulira dotok količine vode iz akumulacijskoga jezera prema vodeničnom kolu tada je spuštena te potpuno zatvara prolaz kako velika količina nadolazeće plimne vode ne bi oštetila vodenično kolo. Kada nastupi oseka i spusti se razina mora ispod osovine vodeničnoga kola, branom se regulira otvaranje prolaza, dotok količine vode $\mathrm{i}$ mlaz koji udara u lopatice i okreće kolo (slike 8c i 8d). Ponovnim nadolaskom plime opisani se proces ponavlja.

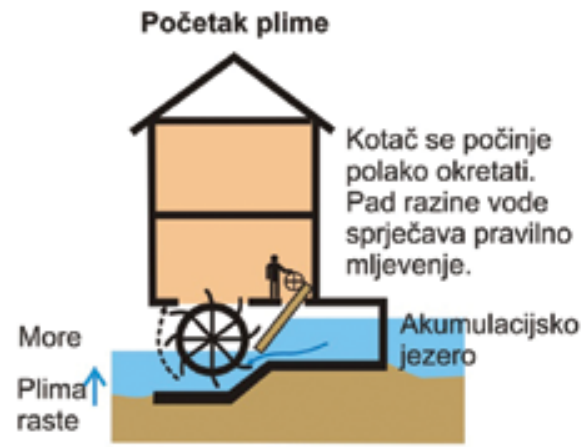

a)

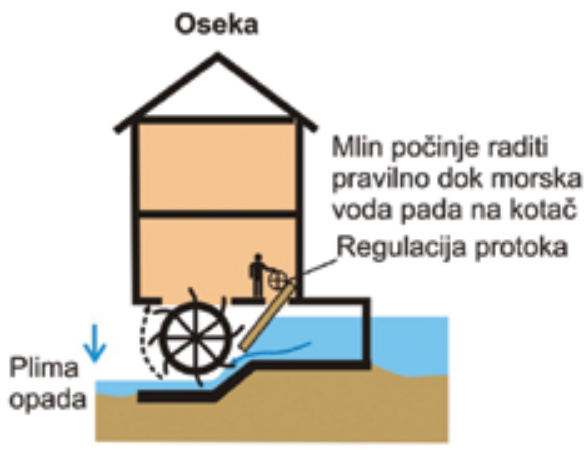

c)

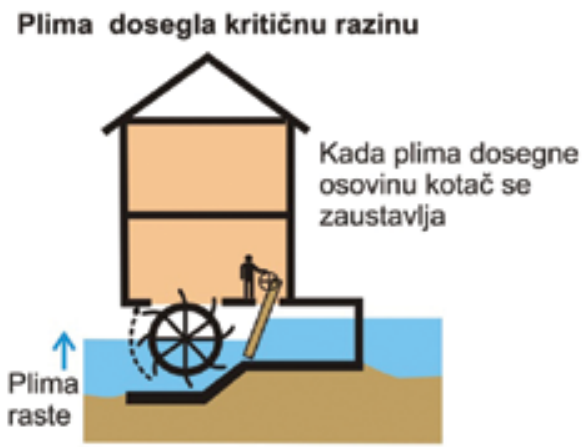

b)

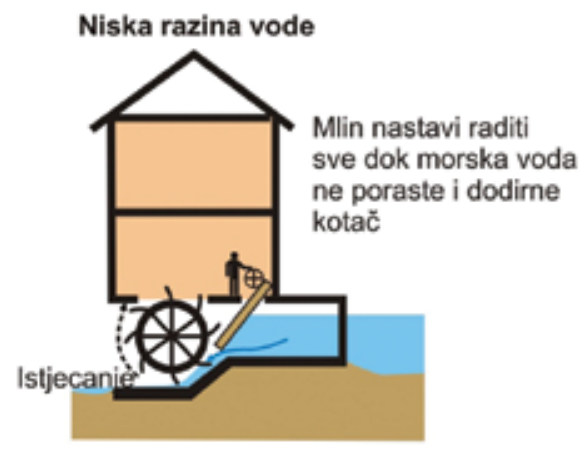

d)

Slika 8. Prikaz rada mlina na plimu i oseku ${ }^{26}$

25 B. Spokes: »Eling Tide Mill«, Mills Archive, 24. II. 2015. (https://millsarchive.org/news/entry/158135/eling-tide-mill\#.W8IjTXszbIU; pristupljeno 1. X. 2018)

${ }^{26}$ Slika dorađena prema B. Spokes: »Eling Tide Mill«, Mills Archive, 24. II. 2015. (https://millsarchive.org/news/entry/158135/eling-tide-mill\#.W8IjTXszbIU; pristupljeno 1. X. 2018) 
Iako kod Elingova mlina nije bio opisan drugi kanal s ustavom za punjenje akumulacijskoga jezera, sigurno je postajao radi omogućavanja brzoga punjenja jezera za vrijeme trajanja plime. Ustava odnosno vrata koja su se otvarala i zatvarala ovisno o plimi i oseci, služeći za punjenje akumulacijskoga jezera, najčešće su podizana vitlom, ali bilo je i automatskih vrata koja su se otvarala pod pritiskom morske vode kod plime i automatski zatvarala kod maksimalne razine pojavom oseke i povlačenjem mora (slika 9). ${ }^{27}$
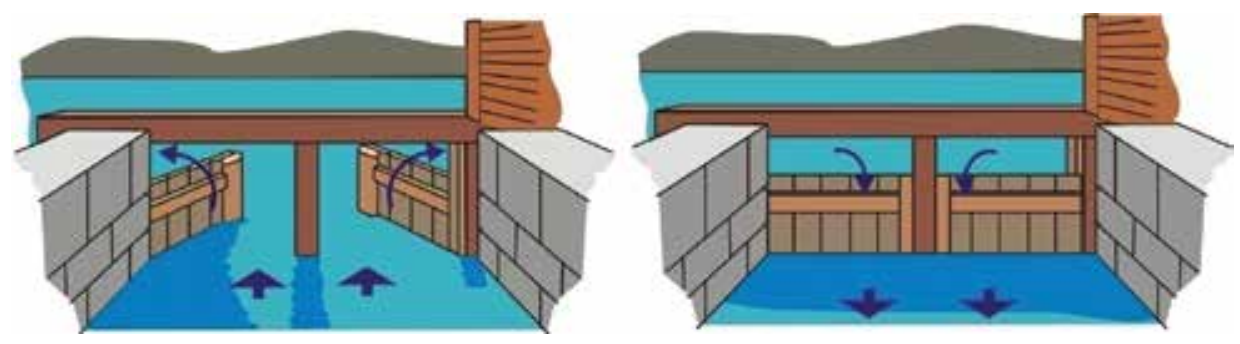

Slika 9. Automatska vrata ustave koja se otvaraju i zatvaraju kod promjene smjera kretanja vode ${ }^{28}$

Na sličnom načelu radili su i drugi mlinovi, što potvrđuje crtež Mariana de Jacopa, zvanoga Taccola, ${ }^{29}$ iz 1438. godine iz knjige De Ingeneis (1427-41) (slika 10). ${ }^{30}$ Preko podignute ustave tijekom plime puštalo se more u akumulacijsko jezero. Kada je započela oseka ustava se zatvarala, a otvarala druga gdje je bio mlin i kolo kojega je tada tjerala voda iz akumulacijskoga jezera. Istim mlinskim kolom nisu se kod tih vodenica mogli koristiti različiti smjerovi istjecanja vode jer suprotni smjer okretanja mlinskih kamena nije bio predviđen u mehanizmu za mljevenje. Na slici 10. desna, veća građevina, osim ustave, sigurno je imala i mlin, koji je najvjerojatnije radio na gore opisanom principu.

$27 »$ Definition of a Tide Mill«, Tide Mill Institute (http://www.tidemillinstitute.org/definitionof-a-tide-mill/; pristupljeno 16. X. 2018)

${ }_{28}$ Nacrtano prema »Definition of a Tide Mill«, Tide Mill Institute (http://www.tidemillinstitute. org/definition-of-a-tide-mill/; pristupljeno 16. X. 2018)

29 Mariano di Jacopo zvani Taccola (1382-1453) bio je poznat kao Arhimed iz Siene. Začetnik je novoga ilustriranoga stila inženjeringa i strojnih priručnika koji su tijekom renesanse postali uobičajeni. Smatra ga se inovatorom mnogih rješenja koje su poslije i drugi preuzimali. Napisao je dva kompleta knjiga s mnogobrojnim crtežima uređaja, strojeva i drugih objekata koji su postali temelj proučavanja njegovih radova: prvi komplet De ingenies (1427-41), u četiri knjige, i drugi De machines (1449) s dodatkom. (https://discoveringdisegno.wordpress.com/2012/11/17/munich/; pristupljeno 2. I. 2018)

30 »Munich«, Discovering designo, 17. XI. 2012. (https://discoveringdisegno.wordpress. com/2012/11/17/munich/; pristupljeno 2. I. 2018) 


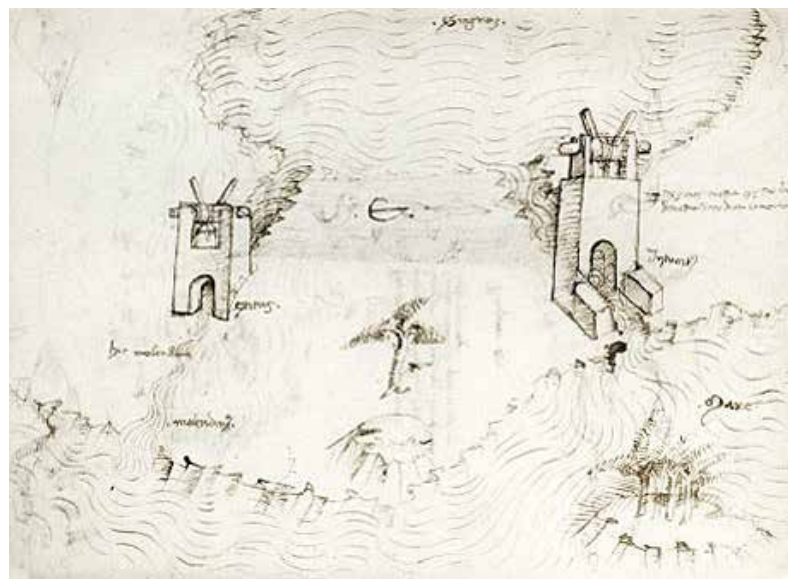

Slika 10. Akumulacijsko jezero s podiznim ustavama i mlinom Mariana Jacopa Taccole, iz knjige De Ingeneis $1427-41 .^{31}$

Mlin na plimu i oseku nacrtao je Faust Vrančić pod nazivom Mlin postavljen na morskom tjesnacu (»Molae in freto maris positae «) (slika 11$)^{32}$. Do sada se nedovoljno detalino tehnički analizirala konstrukcija lopatica toga mlina, kao i cijela koncepcija i način njegova rada.

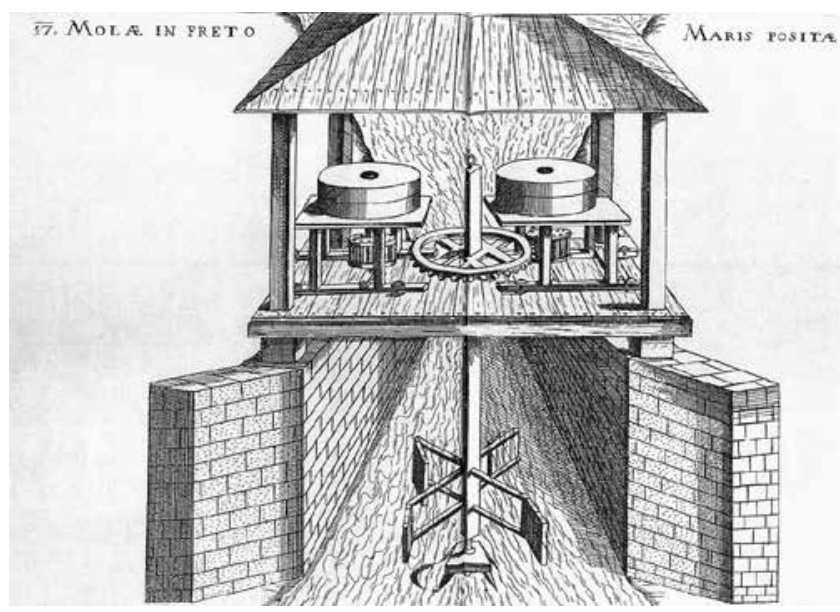

Slika 11. Mlin postavljen na morskom tjesnacu ${ }^{33}$

31 Isto.

32 F. Vrančić: Machinae novae Fausti Verantii Siceni cum declaratione Latina, Italica, Hispanica, Gallica et Germanica. (pretisak), Novi Liber-Gradska knjižnica »Juraj Šižgorić«, Zagreb-Šibenik 1993.

33 Isto, crtež br. XVII. 
Iako Vrančić navodi da mu je to »povjerio jedan dobar prijatelj«, usmjerava opis na iskorištenje plime i oseke, izgradnju akumulacijskoga jezera, a ne na tehničku inovaciju samoga pogonskoga kotača. Upućuje na to da mjesto ulaska vode u kanal za akumulacijsko jezero treba izgraditi na mjestu gdje »nije izloženo bilo kojoj sili valova« te da jezero treba biti duboko »koliko more običava porasti« zbog plime. ${ }^{34}$

Vrančić tekstom ne upućuje na rješenje koje je prikazao crtežom, a koje je, tehnički gledano, varijanta pogonskoga kotača koji je već na neki način razradio za vjetrenjaču kod crteža Mlin na vjetar pod brojem VIII (»Molae velis actae«), što je u to doba bila inovativna i revolucionarna ideja. Sklopive lopatice, ali sasvim drugačije konstrukcije Vrančić je koristio i za vodenična kola.

Vrančićevo rješenje sklopivih lopatica u mlinu omogućuje okretanje vodeničnoga kola uvijek u istom smjeru bez obzira na smjer kretanja vode. Detalji konstrukcije okretišta lopatica nisu sasvim vidljivi na crtežu, ali se može shvatiti funkcija rada. Na slici 12. prikazana su neka od tehničkih rješenja te je analizirano njihovo ponašanje kod promjene smjera tijekom plime i oseke (slika 13). Jasno se uočava da je Vrančić dobro osmislio rješenje i da se vodenično kolo okreće uvijek u istom smjeru (u smjeru kazaljki na satu), bez obzira na smjer vode, što je zasigurno jedno od njegovih originalnih rješenja, njegov izum. ${ }^{35}$ Vodenično kolo položeno je horizontalno, a pogonsko vratilo vertikalno. Kod drugih mlinova uglavnom je obrnuto.
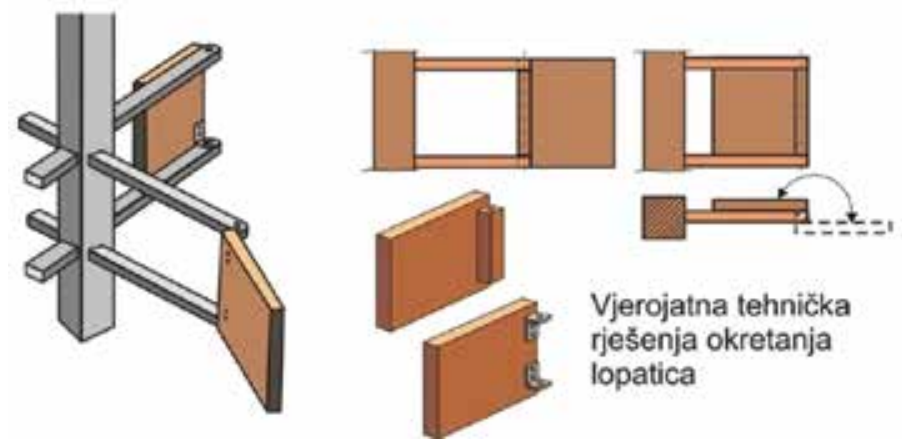

Slika 12. Moguća tehnička rješenja okretanja lopatica oko nosača ${ }^{36}$

Iako o tome Vrančić u objašnjenju crteža ništa ne govori, na crtežu je prikazan ozidani kanal bez ustava u kojem voda očito slobodno struji u oba smjera nastupom

34 F. Vrančić: Machinae novae Fausti Verantii Siceni cum declaratione Latina, Italica, Hispanica, Gallica et Germanica. (pretisak), Novi Liber-Gradska knjižnica »Juraj Šižgorić«, Zagreb-Šibenik 1993.

35 G. Nikolić: Život i izumi Fausta Vrančića, treće prošireno i dorađeno izdanje, HATZ i POUZ, Zagreb 2018.

36 Isto. 
plime i oseke. Treba naglasiti Vrančićevu dosljednost i praktičnost. I kod ovoga je rješenja mlina tehnički riješio korištenje jače ili slabije snage struje mora za pogon mlina. Postavio je, kao i kod većine svojih mlinova na pogon vjetra ili vode, rješenja uključivanja u pogon jednoga ili oba sustava za mljevenje, ostvarivši to na jednostavan i tada jedinstven način primicanjem i odmicanjem kompletnih sustava mlinskih kola, koji se uključuju u zahvat s pogonskim zupčanikom. $U$ ovom slučaju postavio je dva sustava za mljevenje, a kod nekih rješenja vjetrenjača i četiri.
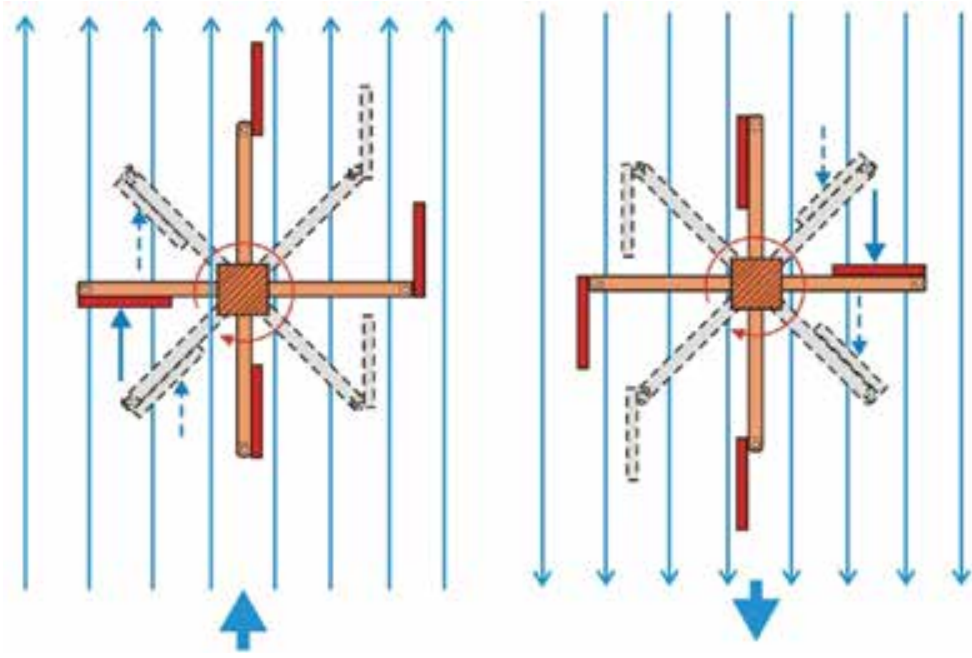

Slika 13. Analiza funkcioniranja Vrančićevih sklopivih lopatica kod sustava pokretanja vodeničnoga kola promjenom smjera strujanja mora tijekom plime i oseke. ${ }^{37}$

Također se može uočiti Vrančićev smisao za praktičnost jer je, kao i kod drugih mlinova vodenica, postavio kuku na vratilu kako bi koloturnicima moglo podizati i spuštati vratilo s pogonskim zupčanikom i pogonskim vodeničnim kolom. Ni ovdje, kao i na mnogim drugim crtežima mlinova, nije nacrtao usipnike za žito i odvod brašna jer se bojao da njihovim dodavanjem slika ne bi bila dovoljno pregledna i ne bi se uočila konstrukcija koju je želio prikazati. Usipnik za žito i odvod brašna standardni su zasebni mehanizmi koji se naknadno postavljaju. Analizom Vrančićeva mlina pogonjenoga plimom i osekom može se ustanoviti da je rješenje vodeničnoga kola sa sklopivim lopaticama originalno te je on izuumitelj toga rješenja, iako se to $u$ literaturi nigdje posebno ne ističe. V. Muljević navodi da je prva hidrocentrala na plimu i oseku izgrađena polovicom XX. stoljeća (1965) u francuskom La Ranceu, na kanalu La Manche. ${ }^{38}$

37 Isto.

38 V. Muljević: Faust Vrančić, prvi hrvatski izumitelj, II. izdanje, Hrvatska zajednica tehničke kulture, Zagreb 2013. 


\section{Turbinski stator i rotor}

Vrančić je želio pronaći tehničko rješenje kako iskoristiti snagu vjetra na lopaticama mlina vjetrenjače, bez obzira na smjer vjetra. Drugi su, poput njegova suvremenika Agostina Ramellija (1531-1610), taj problem rješavali tako da se cijela vjetrenjača okretala prema smjeru vjetra kako bi krila vjetrenjače dobila punu snagu (slika 14).

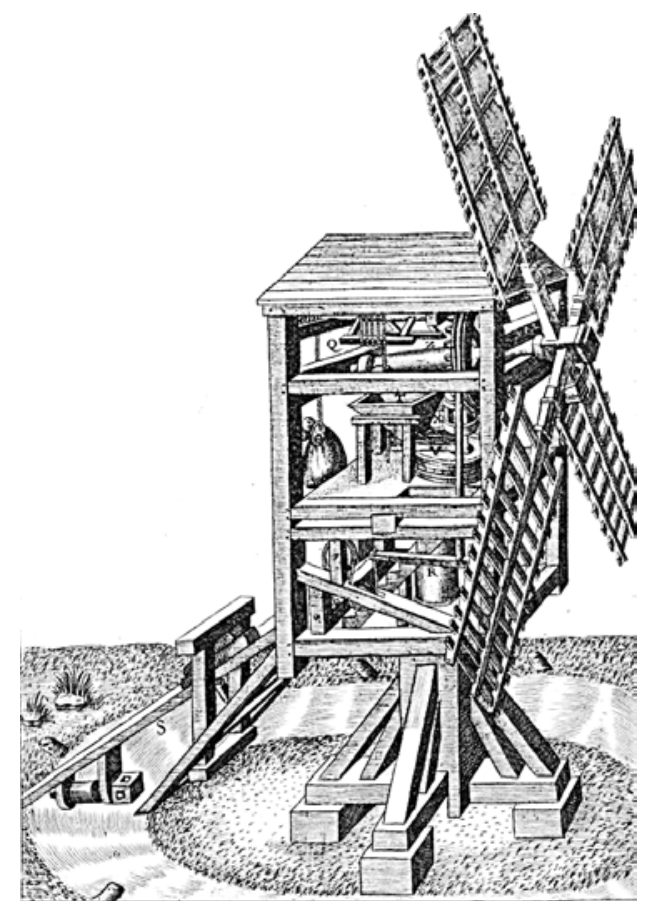

Slika 14. Zakretna vjetrenjača Agostina Ramellija ${ }^{39}$

Vrančić je taj problem riješio na dva različita načina, prikazavši to crtežima. Prvi je način prikazan na Mlinu u četverouglastom tornju (»Molae turis quadrantae«) na slici 15a.

39 »Machines of capitano Agostino Ramelli«, Leo Rugens, 22. VII. 2013. (https://leorugens. wordpress.com/2013/07/22/gianroberto-casaleggio-e-uno-spirito-coerente-e-preveggente/machines-ofcaptain-agostino-ramelli-10; pristupljeno 21/10/2018) 


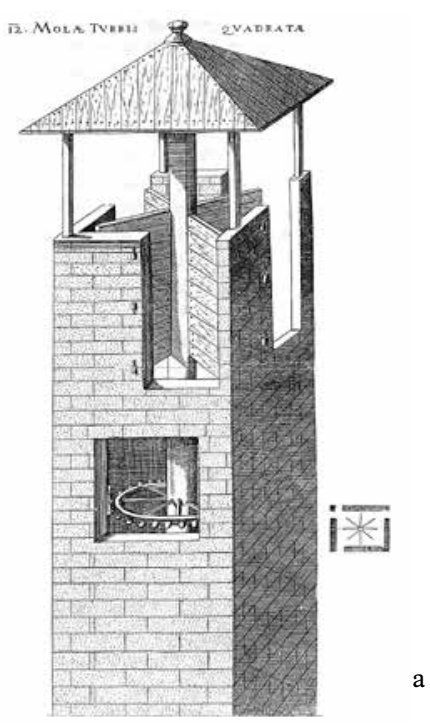

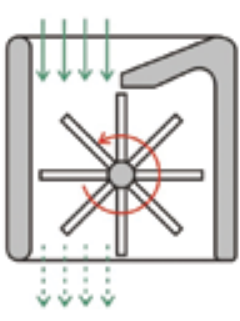

b

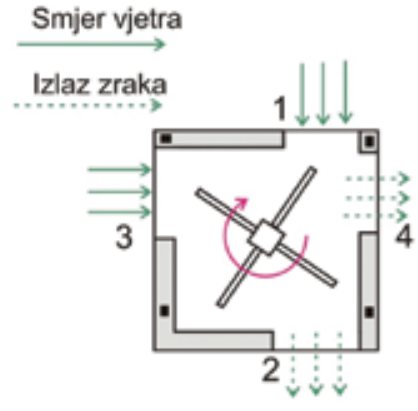

c

Slika 15. a) Faustov Mlin u četverouglastom tornju ${ }^{40}$; b) Horizontalne lopatice vjetrenjače i usmjeravanje struje zraka u Perziji vjerojatno još u VII. st. ${ }^{41}$, a po nekima 500. pr. Kr. ${ }^{42}$; c) Prema crtežu Vrančićeva mlina (a), razrađen prikaz strujanja zraka i smjer okretaja vratila s lopaticama.

Način rada otvora svoje konstrukcije mlina Vrančić objašnjava riječima:

...prozori moraju biti načinjeni jedan nasuprot drugom, da bi vjetar mogao kroz jedan ući, a kroz drugi opet nesmetano izići, ostala dva prozora, koja su izlišna, neka budu zatvorena kako bi vjetar to većom silom propuhao kroz otvorene. ${ }^{43}$

Nije prikazao kako se zatvaraju »nepotrebni« otvori. Sličan način usmjeravanja vjetra na horizontalno postavljen rotor s lopaticama još su davno imali Perzijanaci (slika 15b). ${ }^{44}$ Prikazan način bio je korišten samo za smjer vjetra s jedne strane. S obzirom na to da je želio iskoristiti vjetar koji puše iz raznih smjerova, Vrančić je izveo otvore sa sve četiri strane tornja. Prema crtežu na slici 15c, može se ustanoviti da se samo s

40 F. Vrančić: Machinae novae Fausti Verantii Siceni cum declaratione Latina, Italica, Hispanica, Gallica et Germanica. (pretisak), Novi Liber-Gradska knjižnica »Juraj Šižgorić«, Zagreb-Šibenik 1993.

41 »History of wind power«, Wikipedia (https://en.wikipedia.org/wiki/History_of_wind_power; pristupljeno 21. X. 2018)

42 »A brief story of wind power«, Clean future (http://www.cleanfuture.co.in/2017/05/02/a-briefstory-of-wind-power; pristupljeno 21. X. 2018)

43 F. Vrančić: Machinae novae Fausti Verantii Siceni cum declaratione Latina, Italica, Hispanica, Gallica et Germanica. (pretisak), Novi Liber-Gradska knjižnica »Juraj Šižgorić«, Zagreb-Šibenik 1993.

44 »History of wind power«, Wikipedia (https://en.wikipedia.org/wiki/History_of_wind_power; pristupljeno 21. X. 2018); »A brief story of wind power«, Clean future (http://www.cleanfuture.co. in/2017/05/02/a-brief-story-of-wind-power; pristupljeno 21. X. 2018). 
dva smjera puhanja vjetra rotor okreće $u$ istom smjeru, a $u$ ostala dva u suprotnom. U opisu izuma nije naznačio koji se smjer okretanja rotora traži ${ }^{4}$. Može se pretpostaviti da se koriste smjerovi od otvora 1 prema 2 te 3 prema 4 . Dok je jedan smjer otvoren, kako je Vrančić naveo, zatvaraju se druga dva otvora. Iako je na slici 15c rotor nacrtan samo s četiri krilca, u maloj slici pokraj crteža mlina nacrtano ih je osam, što je vjerojatno pravo rješenje. Bez obzira na korištenja mlina samo za dva smjera puhanja vjetra, to je ipak originalno rješenje i donekle prvi put prikazana neka vrsta usmjeravanja vjetra raznih smjerova posebnim otvorima na lopatice rotora. ${ }^{46}$

Drugo rješenje koje je Vrančić nacr tao i osmislio bio je Mlin u okruglom tornju (»Molae turris rotundae«) na slici 16a i daleko je naprednije. Temeljem toga crteža Vrančića se može smatrati izumiteljem i pretečom statorskoga usmjerivača fluida (voda, zrak, para, plin) na rotor.
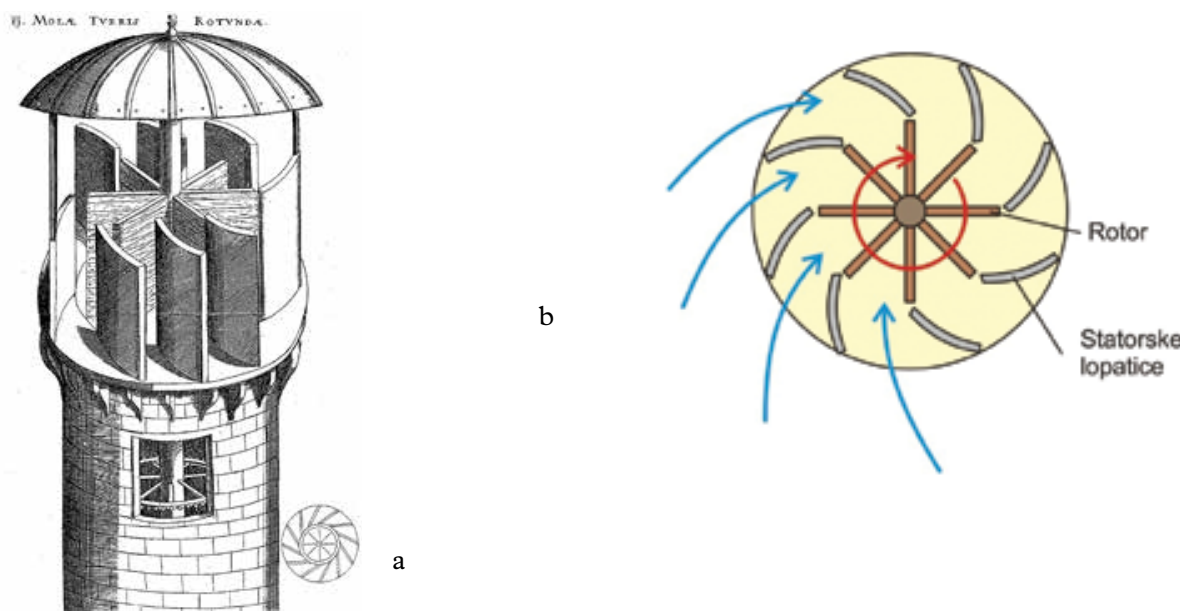

Slika 16. a) Vrančićev Mlin u okruglom tornjü $u^{47}$, b) Stator i rotor Vrančićeva mlina

${ }^{45}$ Vrančić je koristio različita rješenja okretanja pogonskoga kola, bez obzira je se radilo o vodenici ili vjetrenjači. Preko pogonskoga vratila s zupčanikom i prijenosom okretanja na vratilo okretnoga mlinskoga kamena iz njegovih crteža vidljivo je da koristi oba smjera njihova okretanja. Na crtežima br. $9,15,16,18$ i 21 smjer je okretaja mlinskoga kamena u smjeru kazaljke na satu, a kod rješenja na crtežima br. 8, 10, 11, 13, 14, 17 i 23 okreće se obrnutom smjeru. Jedino kod ovoga rješenja na crtežu br. 12 moguća su oba smjera okretanja mlinskoga kamena. Poznavao je, kao i njegovi suvremenici, promjenu smjera okretaja ubacivanjem dodatnoga zupčanika, što je prikazao crtežom br. 9.

46 Kod oba Vrančićeva crteža, 15a i 16a, na maloj sličici desno prikazan je tlocrt usmjerivača vjetra i rotora s pogledom odozdo, suprotno od današnjega načina prikazivanja (op.a.).

${ }^{47}$ F. Vrančić: Machinae novae Fausti Verantii Siceni cum declaratione Latina, Italica, Hispanica, Gallica et Germanica. (pretisak), Novi Liber-Gradska knjižnica »Juraj Šižgorić«, Zagreb-Šibenik 1993. 
Statorske su lopatice koje usmjeravaju struju zraka na rotor zaobljene, što pridonosi boljem usmjeravanju (slika 16b). Vrančić je tu ideju tehnički primijenio na vjetrenjaču, razradio sa svim detaljima i ostvario svoju zamisao da položaj vjetrenjače nije ovisan o smjeru puhanja vjetra niti se, poput onih Ramellijevih (slika 14), treba cijeli objekt okretati prema pravcu puhanja vjetra. Ta je ideja poslije primijenjena i kod vodnih i parnih turbina (slika 17). Moglo bi se prikazati još mnogo primjera te primjene, ali dovoljno je pogledati Francisovu turbinu da se vidi kako se Vrančićeva ideja primjenjuju u suvremeno doba.

Vrančić je uvijek imao na umu povećanje učinkovitosti i primjenom svojih zamisli ostvarivao je veću produktivnost, prikladniji i lakši rad.

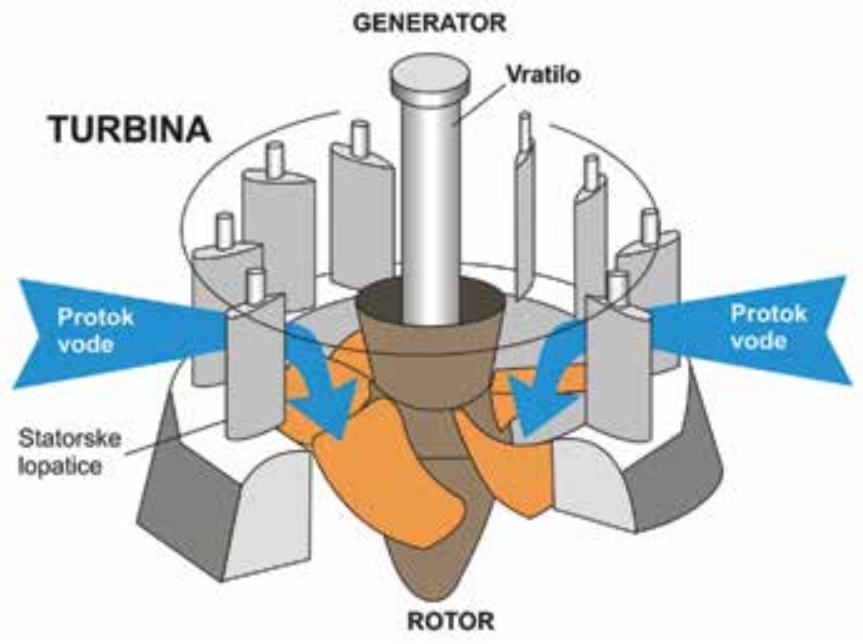

Slika 17. Prikaz dijela Francisove vodne turbine ${ }^{48}$

48 Nacrtano prema: »Energetski sustavi transformacije energije vode hidroelektrane« (https:// www.pfri.uniri.hr/web/dokumenti/uploads_nastava/20180412_095143_vpelic_ENERGETSKI.SUSTAVI.P5.Hidroelektrane.transformacija.energije.vode.pdf; pristupljeno 21. X. 2018) 


\section{Zaključak}

Nije bilo moguće, zbog ograničenja opsega rada, prikazati analizu ostalih vrijednih izuma Fausta Vrančića. Oni uglavnom nisu ni upitni, iako bi se kod nekih moglo zaključcima izmijeniti neka postojeća uvjerenja o njima, kao što se ovim radom pokazalo da Faust Vrančić nije izumitelj padobrana, iako je to njegov zaštitni znak.

Pokazano je da u ključnim detaljima mlina na plimu i oseku, Vrančićev izum mijenja koncepciju rada takvih mlinova i bitno povećava iskoristivost oba smjera strujanja mora. Ovo rješenje upućuje na nepotrebnost drugoga ulaznoga kanala s ustavama.

Postavljanje usmjerivača vjetra (stator) na rotor vjetrenjače kako bi se koristio vjetar iz različitih smjerova originalna je Vrančićeva inovacija koja je stoljećima poslije poslužila i za rješenja usmjerivanja vode, pare ili drugih plinova.

U zaključcima treba još istaknuti, iako nije obrađen ovim radom, nedvojbeno najvažniji izum Fausta Vrančića - ovješeni most (željezni most - »Pons ferreus«). Taj je izum toliko važan da bi trebao biti Vrančićeva ikona, umjesto padobrana, i zvati se po njemu Vrančićev most, a ne ovješeni most. Njemu se ta inovacija priznaje u svim stručnim udžbenicima iz mostogradnje. To je rješenje koje se danas najčešće primjenjuje, iako je takav prvi most izrađen tek 1955. u Švedskoj. U Hrvatskoj su takvi mostovi: Dubrovački most, Domovinski most u Zagrebu te budući Pelješki most. 


\section{LITERATURA}

»A brief story of wind power«, Clean future (http://www.cleanfuture.co.in/2017/05/02/a-brief-story-ofwind-power; pristupljeno 21. X. 2018)

»Abbas ibn Firnas«, Wikipedia (https://en.wikipedia.org/wiki/Abbas_ibn_Firnas; pristupljeno 20. III. 2017)

$»$ Definition of a Tide Mill«, Tide Mill Institute (http://www.tidemillinstitute.org/definition-of-a-tidemill/; pristupljeno 16. X. 2018)

»Energetski sustavi transformacije energije vode hidroelektrane« (https://www.pfri.uniri.hr/ web/dokumenti/uploads_nastava/20180412_095143_vpelic_ENERGETSKI.SUSTAVI. P5.Hidroelektrane.transformacija.energije.vode.pdf; pristupljeno 21. X. 2018)

»History of Parachutes« (https://www.timetoast.com/timelines/history-of-parachutes; pristupljeno 18. X. 2018)

»History of wind power«, Wikipedia (https://en.wikipedia.org/wiki/History_of_wind_power; pristupljeno 21. X. 2018)

»ideja«, Hrvatska enciklopedija, Leksikografski zavod Miroslav Krleža (http://www.enciklopedija.hr/natuknica.aspx?id=26905; pristupljeno 13. X. 2018)

»Leonardo da Vinci, Images and Videos«, Encyclopaedia Britannica (https://www.britannica.com/biography/Leonardo-da-Vinci/images-videos; pristupljeno 5. XI. 2015)

»Leonardo da Vinci’s contemporaries«, Brian Law's Leonardo Da Vinci Models (http://www.leonardoda-vinci-models.com/hints.html; pristupljeno 15. V. 2017)

»Leonardo, Di Giorgio, Taccola, and Alberti« (http://erenow.com/postclassical/1434-year-a-magnificent-chinese-fleet-sailed-italy-ignited-renaissance/17.html; pristupljeno 14. V. 2017)

»Louis-Sebastien Lenormand «, Alchetron (https://alchetron.com/Louis-S\%C3\%A9bastien-Lenormand; pristupljeno 18. X. 2018)

»Louis-Sébastien Lenormand«, Wikipedia (https://en.wikipedia.org/wiki/Louis-S\%C3\%A9bastien_Lenormand; pristupljeno 15. X. 2018)

»Machines of capitano Agostino Ramelli«, Leo Rugens, 22. VII. 2013. (https://leorugens.wordpress. $\mathrm{com} / 2013 / 07 / 22 /$ gianroberto-casaleggio-e-uno-spirito-coerente-e-preveggente/machines-ofcaptain-agostino-ramelli-10; pristupljeno 21/10/2018)

»Mariano di Jacopo Taccola (1382-1453)«(https://www.youtube.com/watch?v=if3hUbIDQys; pristupljeno 15. V. 2016)

»Munich«, Discovering designo, 17. XI. 2012. (https://discoveringdisegno.wordpress.com/2012/11/17/munich/; pristupljeno 2. I. 2018)

"padobran«, Wikipedija (https://hr.wikipedia.org/wiki/Padobran; pristupljeno 10. IX. 2016)

»Swiss jumps using da Vinci-designed parachut«, Chinadaily, 28. IV. 2008. (http://www.chinadaily.com. cn/world/2008-04/28/content_6649092.htm; pristupljeno 18. X. 2018)

»Što je patent?«, Državni zavod za intelektualno vlasništvo, 2015. (https://www.dziv.hr/hr/intelektualnovlasnistvo/patenti/sto-je-patent/; pristupljeno 13. X. 2018)

»The first parachutist«, Bowie News, 22. X. 2016. (http://bowienewsonline.com/2016/10/the-first-parachutist/; pristupljeno 18. X. 2018)

»The Truth About Da Vinci«, Burners.me, 3. XI. 2015. (https://burners.me/2015/11/01/the-truth-aboutda-vinci/; pristupljeno 13. X. 2018)

"vodenice«, Wikipedija (http://hr.wikipedia.org/wiki/Vodenice; pristupljeno 16. X. 2018)

Carrington, D.: »The Da Vinci Parachute«, BBC News Online (http://www.angelfire.com/electronic/ awakening101/davinci-chute.html; pristupljeno 18. X. 2018) 
Hadley-Ives, E. i Chun-Chih.: »Parachute Designed and Invented« (http://www.historylines.net/ history/15th_cent/parachutes.html; pristupljeno 1. XI. 2015)

Mahmutović, E.: »Skok s replikom Vrančićeva padobrana s 1800 m«, Tehnička kultura, 28(2009) 229230, str. 31-33.

Merrill, E. M.: »The Trattato as Textbook: Francesco di Giorgio's Vision for the Renaissance Architect«, Architectural Histories, 2013. (http://journal.eahn.org/articles/10.5334/ah.at/; pristupljeno 18. V. 2017).

Muljević, V.: Faust Vrančić, prvi hrvatski izumitelj, II. izdanje, Hrvatska zajednica tehničke kulture, Zagreb 2013.

Nikolić, G.: Korištenje i plagiranje tudih ideja u renesansi, Zbornik radova s znanstveno-stručnog skupa Povijest i filozofija tehnike, Zagreb 2018., str. 263-302.

Nikolić, G.: Letači fohna Wilkinsa među kojima nema Fausta Vrančića, Znanstveno stručno savjetovanje »4. Kulturno nasljeđe Ujević«, Krivodol, Imotski 2017., str. 151-160.

Nikolić, G.: Život i izumi Fausta Vrančića, treće prošireno i dorađeno izdanje, HATZ i POUZ, Zagreb 2018.

Sparks, I.: »Parachute that Da Vinci drew is made to work... after 523 years«, MailOnline, 28. IV. 2008. (http://www.dailymail.co.uk/news/article-562445/Parachute-Da-Vinci-drew-work--523-years. html; pristupljeno 1. XI. 2015)

Spokes, B.: »Eling Tide Mill«, Mills Archive, 24. II. 2015. (https://millsarchive.org/news/entry/158135/ eling-tide-mill\#.W8IjTXszbIU; pristupljeno 1. X. 2018)

The Domesday Book online (http://www.domesdaybook.co.uk/; pristupljeno 16. X. 2018)

Vrančić, F.: Machinae novae Fausti Verantii Siceni cum declaratione Latina, Italica, Hispanica, Gallica et Germanica. (pretisak), Novi Liber-Gradska knjižnica »Juraj Šižgorić«, Zagreb-Šibenik 1993.

White, L. Medieval Religion and Technology. Collected assays, 1978. (https://books.google.hr/books?id= quCh9tAWljcC\&printsec $=$ frontcover\&hl=hr\#v=onepage\&q\&f=false; pristupljeno 6. XI. 2015)

Wilkins, J. C.: Mathematical Magick: or the Wonders that may be Performed by Mechanical Geometry, I. i II. dio, 1680. (https://reader.digitale-sammlungen.de/de/fs1/object/display/bsb10922793_00005. html; pristupljeno 6. XI. 2015). 


\title{
THE ORIGINALITY OF FAUST VRANČIĆ'S INVENTIONS
}

\author{
Gojko Nikolić \\ Faculty of Textile Technology, University of Zagreb \\ gojko.nikolic@ttf.hr
}

\begin{abstract}
Based on the current understanding of the term 'invention', this paper examines the originality of three of Faust Vrančićs inventions. The first invention studied in the paper is the parachute; it is concluded that Faust did not invent it, but made an exceptional technical contribution to its design that is very similar to modern technical solutions. Since he is widely considered the inventor of the parachute, many will be surprised to learn that this is, in fact, not true. The second analysed invention, which is insufficiently publicised today, is Vrančić's tide mill. His idea was not new, as it had been employed long before his lifetime, especially in Ireland and England. The innovation in Vrančićs mill is the use of the bidirectional tidal current, with the water wheel being constructed in such a way as to always turn in the same direction regardless of the tidal current. The third innovation, involving Vrančić's solution to the application of stators and rotors on windmills that enables harnessing the wind from any direction, is today used in turbines for various fluids (water, steam, gases).
\end{abstract}

Keywords: parachute; tide mill; Faust Vrančić; windmills 